\title{
Removal of Nuns from South Bohemian Hospitals by the Communist Regime and Its Impact on Pastoral Care of Patients
}

\section{Martin Weis}

\section{Introduction}

After February 1948 gradual circumscription of religious life in the state began. The Communist regime in Czechoslovakia strove to dominate the Christian churches. It did so primarily by power means - it disabled adequate reaction of the churches to social changes in Czechoslovakia, confiscated the economic foundation of the churches, and also gradually removed many church representatives and interned or imprisoned them as a result of political trials using trumped up charges. ${ }^{1}$

A further aim of the communist power was first to push external manifestations of the religious life of the inhabitants of Czechoslovakia out of public life and public space into enclosed places of worship, which were then to be gradually limited in number, as the number of those for whom it was necessary to provide so-called "religious self-realization" was to decrease according to the expectations of those in power. That also entailed constraints on the possibilities of pastoral care of patients in public hospitals. The procedure progressed from removal of crosses from public spaces in hospitals through abolition of hospital chapels to expulsion of nuns from hospitals, in order to prevent them from "having negative worldview influence" on patients as well as hospital personnel. Eventually, all that was left to priests for pastoral care of patients was a short allotted space of quiet conversation with the patient within so-called visiting hours of patients by relatives and friends.

This study aims to describe the removal of nuns from hospitals in the South Bohemian region and the subsequent negative impact on pastoral care of patients, based especially on archive materials as well as scholarly literature. Due to the extent of the topic only larger hospitals in which the congregation of the Merciful Sisters of St. Charles Borromeo was operating were selected in the study, namely those in České Budějovice, Jindřichův Hradec, Písek, Pelhřimov, Strakonice and Tábor.

1 Cf. Václav VAŠKO, Neumlčená: Kronika katolické církve v Československu po drubé svètové válce I, Praha: Zvon, 1990, pp. 243-245. Further cf. Václav VAŠKO, Dỉm na skále 1, Církev zkoušená: 1945 - začátek 1950, Kostelní Vydří: Karmelitánské nakladatelství, 2004. On the issue of political Catholicism one can boldly recommend the highly erudite monograph by Petr FIALA, Český politický katolicismus 1848-2005, Brno: Centrum pro studium demokracie a kultury, 2008. 


\section{On the issue of literature and sources}

On the issue of persecution of monks and nuns by the communist regime several monographs, studies and qualification theses have already been published. It is due to state, however, that they touch on our issue only marginally or in a partial manner. ${ }^{2}$

The most valuable source of information on the issue under scrutiny are the state archives, in which materials of state officials of the South Bohemian region, whose competency was so-called surveillance of state over churches, are deposited. Materials of their activity are concentrated in the State Regional Archive in Třeboň and partially also in district archives, as part of the archive funds of KNV (Regional National Committee) and ONV (District National Committee) - church departments. In this study archive materials in possession of the author have also been used, which he acquired while collecting documents bearing on the Bishop of České Budějovice Josef Hlouch, since they show the Bishop's reaction to the liquidation of religious life in his diocese. Printed archive materials such as the diocesan catalogue or official bulletins and circular letters of the civil service were also not omitted. Where it was necessary for setting the issue in broader context materials from central archives - e.g. materials of the State Office for Church Matters in Prague are also quoted.

\section{The situation of nuns and pastoral care of patients after 1948}

Looking in the rigorously elaborated diocesan catalogue, we see that on January $1^{\text {st }}, 1948$ altogether 612 nuns were active in the diocese of České Budějovice, of which 163 were Borromeo sisters. These worked especially in the district and municipal hospitals. The catalogue states that there was a collective of 42 sisters in the district hospital of České Budějovice, in the district hospital of Jindřichův Hradec there were 8 sisters, in the municipal hospital of Pelhrrimov there was a collective of 18 sisters, a community of 14 sisters worked in the district hospital in Písek and 8 sisters were active in the district hospital in Počátky. In the district hospital of Tábor a collective of 18 nuns is mentioned and 15 sisters in the district hospital of Strakonice. The longest standing activity of the Borromeo sisters was in the district hospital in České Budějovice, where they had been according to the catalogue already since $1850 .^{3}$

For comparison, the Prague archdiocesan catalogue of 1948 states that altogether 417 Borromeo sisters were active in the archdiocese, in thirteen places. ${ }^{4}$

2 As basic literature introducing the topic let us mention the monograph by Ludvík JIRÁSKO, Církevní rády a kongregace $v$ zemích Českých, Praha: Fénix, 1991. The specific Slovak issue of relationship of the communist state power to female orders and congregations is introduced e.g. by the erudite monograph by Jan Milan DUBOVSKÝ, Akcia reholníćky, Martin: Lúč, 2001. On the issue of Borromeo sisters let us mention the monograph concerning the "main heroine" of the congregation in the era of communist totality: Marie HOLKOVÁ, Matka Vojtěcha - Vyprávění o velkéslužebnici Boǒ̌í, Brno: Cesta, 1992. On related issues of the South Bohemian region I point out the monograph by Zdeněk DEML, Pod dobledem cirkevních tajemnikư, Brno: CDK, 2008. This monograph is de facto a revised version of the author's dissertation thesis, successfully defended at TF JU in České Budějovice in 2008, dealing especially with the issue of rescription of liturgical life of the Church in the South Bohemian region on selected examples. We must also not omit a study in which the author points out the sly methods used by the communist state power in persuading nuns to leave their order and depart for civil life. Cf. Martin WEIS, Přesvědčovací akce „svlékni hábit“ve světle archivních materiálů, Studia theologica 3/2009, pp. 63-76.

3 Catalogus saecularis et regularis cleri dioeceseos Bohemo-Budvicensis pro Anno Domini 1948 (further CCB 1948), pp. 182-186.

4 Cf. Catalogus cleri archidioeceseos Pragensis Anno Domini 1948, pp. 290-292. 
After the events of February 1948, already in December of the same year, hospitals were nationalized, which, however, had no impact on the South Bohemian region with respect to spiritual care of patients. But e.g. in Prague the Hospital Pod Petrrínem, formerly belonging to the Borromeo sisters, was nationalized, becoming a subsidiary of the State Faculty Hospital in Prague. The Borromeo sisters continued to operate in their places in the hospital, but already in August 1952 they were expelled from the hospital and most sisters were transferred to textile factories.

When the Communist Party of Czechoslovakia seized power in the state in February 1948, gradual restriction of ecclesial life in the state followed. That was reflected also in the possibilities of pastoral care of patients by clergy. First, crosses were removed from public spaces in hospitals by order of the communist power organs. Of course, that did not happen without protests on the part of the faithful hospital personnel as well as faithful patients. The situation was eventually solved by the Minister of Health Care Josef Plojhar. Because in negotiating between the state and the Catholic Church he wished to show what political influence he had, he ordered that crosses be returned to hospitals and had them placed even where they had not been before - in private offices of head physicians and department heads. That is testified e.g. by the discussion contribution of the Regional Secretary of the Communist Party of Czechoslovakia, in which he literally states the following: "Plojhar intervenes in matters that are not in his competence, e.g. in hospitals where our comrades wanted to take down crosses. Minister Plojhar revoked that and wants to place crosses even where they had not been before. E.g. in the private offices of head physicians. The Minister wants to show Bishop Hlouch his power and it will cost 10,000 Czk..."5 On the other hand, for the sake of objectivity it is necessary to admit that the clergy were not restricted in administering sacraments, spiritual conversations with patients, and similar things. Administering some sacraments was restricted in hospitals only in 1952, namely regular celebration of holy mass for the public or administering baptism. This fact is evinced by the sharp drop in the number of the baptised recorded in the Parish Register of the Roman Catholic parish of Tábor, where the number of baptisms dropped in one year from 988 to 303, since they were prohibited for health reasons based on a proposal of the Health Secretary. ${ }^{6}$

In 1955 the State Office for Church Matters in Prague introduced a unified plan for all of Bohemia to the effect that religious acts were to be tolerated in patients' rooms only in case of the so-called last unction, whereby the clergy were strictly prohibited to do socalled campaigning among the patients on this occasion. Baptisms were to be eliminated from hospitals - maternities. Of course there was an exception, which the relevant Church Secretary could authorize, in case of so-called "extraordinary political interest". ${ }^{7}$

5 Cf. SOA Třeboň, Fond Jihočeský krajský výbor Komunistické strany Československa (further Jč KV KSČ), file no. 25, signature I/141, General Assembly of South Bohemian Regional Committee of the Communist Party of Czechoslovakia 1949, typed record of comrade Holub's report.

6 Cf. Roman Catholic Parish Tábor, Book of Baptisms. Entries of 1952 and 1953. As Zdeněk Deml states in his monograph, the whole situation concerning the prohibition of baptisms in the hospital chapel in Tábor was initiated by the complaint of the Secretary for Church in České Budějovice, who in his letter to the State Office for Church Matters in Prague proposes that hospital chapels serve only "the private needs of nuns - nurses". Cf. Zdeněk DEML, Pod dobledem cirkevních tajemnikiu, p. 178.

7 Ibid, pp. 146-147. 
Of course, as many representatives of the communist regime in hospitals or local state administration were apt to resent, there were many nuns who invited patients in their chapels, and there were also many clergymen who, although they had state consent only for spiritual service to the collective of nuns, nonetheless secretly carried out pastoral care among the patients, which was labelled "inimical campaigning". The issue of hospital chapels and sacrament administration was only "solved" to the satisfaction of regime representatives by definitive removal of nuns from hospitals and closing down of hospital chapels, which were transformed to wards, cultural rooms with television, or even deposits of civil defence. All that was left in hospitals was sporadic administration of the sacrament of reconciliation and anointing of the sick, and it often depended on great courage and ingenuity of the priest or the patient's relatives that this form of pastoral care of patients was performed.

\section{The situation of nuns in South Bohemia after 1950}

Since 1950 the communist state power in Czechoslovakia strove to abolish female orders and congregations, or at least to radically restrict their existence, which of course also had negative impact on pastoral care of patients in hospitals where the nuns had been active. It is certain that many nuns found it difficult to bear the increasing pressure of the state power, so that a beautiful testimony has been handed down relating how already in March 1950 the Bishop of České Budějovice Josef Hlouch escaped from the internment in his residence in order to empower the nuns for the coming moments of trial by spiritual word and blessing. The security officer of the relevant District National Committee complains in his note that it was actually with the help of the hospital personnel and silent consent of the local Communist Party unit: "On March 25 ${ }^{\text {th }}, 1950$ at 6 p.m. I learned that the following day, i.e., on March $26^{\text {th }}, 1950$ Bishop Hlouch was to visit Strakonice. I therefore ordered the organs of National Security to follow the matter. From the report I also note that the administration of the local state district hospital did not report the visit of the Bishop of České Budějovice to the local District National Committee, although it was informed of it, and the head administrator of this hospital comrade Josef Kahuda furnished his own private car for the transport of Bishop Hlouch from České Budějovice to Strakonice and back. Even the Base Unit of the Communist Party in that named hospital, although it was aware of the visit, did not inform the responsible Party organs of the matter..."

Several days later there came a trial on trumped-up charges with representatives of orders, taking place March $31^{\text {st }}-$ April $5^{\text {th }}$, 1950. Then on April $13^{\text {th }}, 1950$ monasteries were seized in a night police raid and the monks were deported to so-called concentration or internment monasteries. There followed administrative restrictions on the activity of nuns and their transfer to so-called "centralization" cloisters. Unlike the crackdown on male orders, the crackdown on female religious communities did not take place in only one day, but was distributed approximately from August to October 1950. Altogether about seven hundred cloisters were abolished and more than 10000 nuns interned in all of Czechoslovakia. ${ }^{9}$ As we have already stated elsewhere, the nuns' stay in centralization cloisters was fairly

8 SOA Třeboň, fond Jč KNV České Budějovice, carton no. 146, signature 370, report of ONV Strakonice to the regional church secretary of March 27th, 1950, manuscript, original, signed.

9 Cf. Václav VAŠKO, Neumlčená, p. 191. 
hard. ${ }^{10}$ Each centralization cloister had its head, without whose consent no one could visit the nuns. Persons wishing to apply to visit a nun were obliged to fill in a very thorough questionnaire, in which there were both the personal data of the applicant and the nun to be visited and also pertinent "justification" for visitors of the centralization cloister why they do so. Although the form contained the assurance that the right to visit the nuns is thereby in no way restricted, it in fact depended on the will of the state administrator of the cloister whether s/he would allow the visit, or refuse it on the pretence of political or health reasons. ${ }^{11}$

First the nuns in the "exposed" places were forced to leave their place of work, i.e., the ones in schools and more prominent hospitals, where they could "improperly" ideologically affect the broad masses of the working people. They were concentrated in centralization cloisters or transferred to institutions of social care where they encountered mostly only over-aged or mentally ill persons. Where nuns could not be removed immediately due to necessary care for patients, they could work for some more time. But they were subjected to strict ideological examinations and rough intervention in the internal self-government of the religious community. ${ }^{12}$

The report of the regional church secretary in České Budějovice shows that not everywhere did district church secretaries pay due attention to nuns and in 1952 there were still "serious shortcomings" in this work, especially concerning nuns working in district hospitals. ${ }^{13}$

These "shortcomings" in the work of district church secretaries persisted to further years, and so we can still in 1955 find a very harsh evaluation of the nuns' collectives: "Nuns in the South Bohemian region, especially those working in hospitals, do not have a positive relationship to our establishment and easily let themselves be used for political interests of the reaction. This manifested itself in the region especially at the elections, when despite all effort $41 \%$ of nuns refused to take part in the elections. The most reactional collective are the nuns in České Budějovice, who e.g. at the elections to the National Assembly put mostly closet paper in the ballot boxes. This collective of nuns often meets reactional priests operating in České Budějovice." ${ }^{14}$

This fact was also probably the reason why in 1956 the Borromeo sisters working in five district hospitals were removed from the diocese of České Budějovice. A highly moving document has been preserved depicting the reaction of the diocesan Bishop Josef Hlouch to this removal of nuns from the diocese. It is particularly remarkable that this document came to existence already at the time of strict internment of the Bishop outside the diocese. The letter got from the internment to the nuns probably by being "carried through" by one

10 Cf. Martin WEIS, Přesvědčovací akce, p. 67.

11 Cf. original of the registration card in SOkA Jindřichův Hradec, fond ONV Dačice, carton no. 679, folder cloisters.

12 Cf. Martin WEIS, Přesvědčovací akce, p. 68.

13 Cf. SOkA Písek, fond ONV Milevsko, carton no. 125, signature 291.5, typescript, original, signed on November 17th, 1952.

14 By those "reactional priests" the church secretary meant those clergy of Ceské Budějovice who regularly spiritually cared for patients by administering sacraments or spiritual conversation. The documents most often mention the name of chaplain P. Škopek. SOA Třeboň, fond KNV České Budějovice, carton no. 691, folder círk./3 - Meeting of bureau of KV KSČ in Č. Budějovice on March 31st 1955 . Report on church-political development in the region Č. Budějovice (presented by c. Krejčí) - manuscript, original. 
of the Bishop's authorized visitors. The letter is signed by the Bishop's own hand, written on a standard format A4 sheet of paper. The paper has no letterhead or Bishop's sign.

Unfortunately it also bears no date of writing, and therefore we can only by its content judge that it was written before the feast of Visitation in 1956, i.e., before July $2^{\text {nd }}, 1956 .{ }^{15}$ Even in the very harsh conditions Bishop Hlouch found words of gratitude and encouragement for the nuns forced to leave their place of work. The entire text of the letter reflects the Bishop's loving heart and his deep Eucharistic spirituality, when as one of the most painful consequences of the departure of nuns from hospitals he sees the fact that the Eucharist will be removed from hospital chapels and patients will thus lose the supernatural source of consolations. The words of blessing point to the other - Marian - dimension of Bishop Hlouch's spirituality: "Let the Lord God accompany you, let Virgin Mary the Immaculate Mother be with you, who certainly takes special care of you, as God suggests, since you are leaving on the feast of Her Visitation. Let your souls on this day sound a humble Magnificat, which nothing will tear out of those hearts or subdue, and which will outvoice all the cry of the godless world and the cry of all adversities." But the letter also contains words of hope that when God allows some blessed work to be torn down, he does that because he will build up. The Bishop concludes the words of encouragement with an exclamation addressed to the future: "And the Lord God will build up!"16

However, this letter also documents the role the nuns had with respect to patients in spiritual care:

"As an order you were a focal point of exemplary life and excessive merits in our towns and regions. Your Bishop and your priests relied on you, took recourse to you, begged for your prayers, when there were great anxieties in the Kingdom of God, when they often succumbed in a sea of affliction and hardships, when they were falling under the weight of crosses. Only our Father knows what fortresses of God's Kingdom those times of yours were, those hospital chapels, yes even those niches of your night watches, where you were awake with the rosary and a pious book in prayer waiting for a patient to call, from where you hurried with quiet step to see whether a patient perhaps needs help. Since it is not possible to do justice to the goodness of God, it is difficult to do justice to all that blessing, all the light, strength and all external grace that our regions have received through you (...). ${ }^{17}$

\section{Slovak nuns in Bohemia}

In connection with the situation of nuns in Bohemia it is also necessary to mention the situation of Slovak nuns, who were for the most part removed to Bohemia. As in Bohemia,

15 Bishop Josef Hlouch went through several phases of internment and restriction of personal freedom. The first restriction came already on June $17^{\text {th }}, 1949$ by the installation of the so-called government commissioner into the episcopal office and subsequent seizure of the curia premises with police assistance. The next phase came in February 1950, when Bishop Hlouch was assigned so-called "personal protection", i.e., he was accompanied everywhere by a State Security officer, who also patrolled the episcopal office building and checked all incomers. Beginning June 1950 there followed strict isolation of the Bishop in the residence building, during which only the state-installed Vicar General Buchta, the state commissioner and two nuns had access to the Bishop. In 1952 Bishop Hlouch was removed from the diocese and the Vicar General Josef Buchta was installed in his place by fictitious election. The Bishop left internment only at the time of political changes in our state in 1968. Cf. Martin WEIS, Přesvědčovací akce, p. 69.

16 Document original in possession of Bishop Hlouch's family.

17 Ibid. 
in Slovakia a sharp intervention in the life of female orders also took place and more than 2,000 nuns were transported from their places of work to so-called centralization cloisters. As the Slovak Office for Church Matters in Bratislava deemed that despite this intervention the

religious life of Slovak nuns had not been paralyzed, they arranged with the State Office for Church Matters in Prague for the removal of Slovak nuns to Bohemia, where they were to be engaged exclusively in manual work in textile factories in the depopulated North Bohemian border region. This transfer of Slovak nuns took place in three phases, on October $12^{\text {th }}$, 1951330 nuns were removed, on October $20^{\text {th }}, 1951460$ nuns were removed, on October $21^{\text {st }}, 195179$ nuns were removed. As it gradually became possible also in Slovakia to replace the collectives of nuns in hospitals with lay nurses, these nuns were also transferred to Bohemia. Statistics tell us that in the subsequent years up to 1961 further 230 nuns were thus removed from Slovakia to Bohemia. These nuns, as planned, worked in factories and could not visit their home Slovakia even at the time of so-called legal leave for recovery. Only in the 1960s did they obtain the opportunity to leave the factories and work in Bohemia in social services, especially in homes for the elderly and institutions for the mentally ill, and thus bring the light of Christian mercy to the ill and the elderly. ${ }^{18}$

\title{
Conclusion
}

When the number of religious communities was radically reduced in the diocese in 1956, nuns continued to be active only in a few places in the diocese. Not even the period of political liberalization in 1968 brought some marked change in this respect. It was too short to allow for full revival of the life of religious communities, and in the subsequent period of so-called normalization state control over the churches, including the activity of religious communities, was intensified again. Pastoral care of the ill thus remained limited to those priests who had so-called state permission to perform spiritual service and who could do so, unless of course the running of the hospital or prohibition of attending physician prevented it.

\section{Removal of Nuns from South Bohemian Hospitals by the Communist Regime and Its Impact on Pastoral Care of Patients}

\begin{abstract}
After February 1948 gradual circumscription of ecclesial life in the state began to take place. The communist authorities in Czechoslovakia sought, inter alia, to radically reduce the activities of female religious orders mainly in exposed areas such as education and public health care. First, on 13 April 1950, during a night raid, the police seized monasteries and the monks were taken to so-called "concentration" or internment monasteries. Then administrative restrictions on the activity of nuns and their transfer to so-called "centralization" cloisters followed. Those measures had a very negative impact on spiritual care of patients in town and district hospitals in the South Bohemian region, as documented by this study based on archive materials.
\end{abstract}


Keywords:

church history, pastoral care of patients, nuns, communist regime, persecution of nuns

\section{Contact}

\section{Prof. Dr. Martin Weis}

University of Souht Bohemia, České Budějovice

Faculty of Theology, Department of Theological Disciplines

Kněžská 8, 37001 České Budějovice

weis@tf.jcu.cz 